Моісєєва Н. І., Романова С. С.

\title{
ФІЛОСОФІЯ ІСТОРІЇ В КОНТЕКСТІ ЛІНГВІСТИЧНОЇ (НАРАТИВНОЇ) ФІЛОСОФСЬКОЇ ТРАДИЦІї
}

Розглянуто проблему дисииплінарного статусу лінгвістичної (наративної) фрілософії історії в контексті аналізу ї̈ базових умов. Автори доводять, щзо, незважаючи на критику класичної історіософії представниками зазначеної філософської традицї, лінгвістична філософія історії по суті виходить із базових положень класичної історіософії.

Ключові слова: філософія історії, філософія мови, лінгвістична традиція філософріі історії, аналітична філософія.

The article deals with the disciplinary status of linguistic (narrative) philosophy of history in the context of analysis of its basic premises. The authors of the article prove the thesis: the linguistic philosophy of history has originated from the basic provisions of classical historiosophy.

Keywords: philosophy of history, language philosophy, linguistic tradition of philosophy of history, analytical philosophy.

Рассмотрена проблема дисииплинарного статуса лингвистической (нарративной) философии истории в контексте анализа ее базовых предпосылок. Авторы доказывают, что, несмотря на критику классической историософии представителями указанной философской традиции, лингвистическая философия истории по существу исходит из базовых положений классической историософии.

Ключевые слова: философия истории, философия языка, лингвистическая традиция философии истории, аналитическая философия.

У сучасній філософській літературі термін «філософія історії» застосовують для позначення як теорій (чи концепцій) історичного процесу, так і методології історичного знання. Іноді для розмежування цих двох аспектів використовують дефініції «історіософія» та «історична епістемологія». Термін «історіософія», уведений у першій половині XX ст. для опису гегелівської концепції світової історії як вияву світового духу, згодом перенесено на всі концепції філософії історії, спрямовані на осягнення закономірностей історичного розвитку (проблеми першопричини й цілеспрямованості історії, прогресу й регресу, універсальності й розгалуженості, детермінізму й свободи волі). Як філософія історії історіософія опрацьовує світоглядні проблеми, які $є$ методологічно важливими для історії, але через специфіку предмета дослідження не можуть мати вичерпного емпіричного підтвердження і, відповідно, однозначного вирішення.

Саме зневіра в можливості адекватного пізнання буття через свідому діяльність у першій половині XX ст. викликала до життя так званий лінгвістичний поворот у філософії. Сутністю цього повороту став перехід від класичної філософії, що розглядала свідомість як вихідний пункт філософського аналізу, до філософії 
некласичної, котра виступає 3 критикою метафізики свідомості й звертається до мови як iі альтернативи. Основними рисами лінгвістичного повороту $є$ відмова від гносеологічної й психологічної проблематики, критика поняття суб'єкта, звертання до дослідження смислу й значення, заміна поняття істинності поняттям свідомості, прагнення розглядати мову як граничну онтологічну підставу мислення й діяльності. Саме під впливом цього повороту сформувалися такі філософські течії, як аналітична філософія, постструктуралізм, семіотика, на які в цілому й орієнтована історична епістемологія. При цьому необхідно відзначити, що сама проблематика критики історичних джерел (походження інформації, джерела їі історичності, суб'єктивність дослідника, інформаційна вичерпність джерела) у руслі епістемологічної лінгвістичної традиції не розглядаються. Натомість у класичній історіософії досвід лінгвістичного повороту, як правило, не враховується.

У зв'язку з цим на перший план виходить проблема співвідношення епістемологічної «філософії мови» (наративу) і філософії історії як теорії історичного процесу. Певним чином у своїх дослідженнях вивчення проблем сучасного стану лінгвістичної (наративної) філософії історії торкалися Н. Бондаренко, І. Дьомін, І. Інішев, Ф. -В. фон Германн, М. Кукарцева. Останні досягнення філософських теорій історичного процесу фіксуються в працях О. Воронянського, І. Денисенко, С. Кірдіної, О. Михайлюка, П. Турчина, С. Коротаєва. Однак низка питань, що не входили до предмета їхього аналізу, залишаються нез'ясованими. Перш за все це проблема базових передумов, на які спирається лінгвістична (наративна) філософія історії. 3 указаної проблеми випливає питання, наскільки відрізняються ці передумови від вихідних положень історіософських концепцій історичного процесу. Пропонована стаття ставить за мету розглянути цю проблематику.

Розглянемо трактування філософії історії в контексті лінгвістичної традиції. Зазначимо, що самі представники цієї традиції іменують іiі аналітичною, протиставляючи свої методи «метафізичній» логіці соціального детермінізму в історіософії [7]. Найбільш яскраво сутність сучасного етапу розвитку епістемологічної філософії наративу відображена в роботах А. Данто та Ф. Р. Анкерсміта.

Наслідуючи традицію, започатковану класиками епістемологічної (аналітичної) філософії Г. Фреге та Л. Вітгенштейном, А. Данто вбачає завдання філософії не в тому, щоб «роздумувати чи говорити про світ», а скоріше в тому, щоб «аналізувати способи роздумів і висловлювань про світ» [4, с. 7]. «Оскільки у нас немає іншого доступу до світу, крім як через мовчання та мову, остільки, навіть обмежуючись розглядом останніх, ми навряд чи зможемо уникнути будь-яких тверджень про самий світ. Філософський аналіз наших способів роздумів і висловлювань про світ стає, урешті-решт, загальним описом того, як ми зобов'язані уявляти світ за існуючими способами мислення та мови. Коротше кажучи, систематично застосовуваний аналіз призводить до дескриптивної метафізики» [4, с. 7]. Стосовно філософії історії це означає, що ііі предметом може бути не минуле саме по собі й не історія як всесвітньоісторичний процес, а лише мова історико-графічних описів. Аналітична філософія історії накладає заборону на висловлювання про історію саму по собі, поза її мовною 
(історико-графічною, наративною) репрезентацією.

Аналітична філософія історії протиставляє себе класичній філософії історії, яку А. Данто визначає як субстантивну. Згідно з його роздумами, ця субстантивна філософія історії претендує на опис і пояснення «всієї історії», проте пї конструкти логічно нестабільні. Головну неспроможність історіософських побудов А. Данто вбачає в тому, що «філософ-субстантивіст» не тільки фактично, але навіть гіпотетично не може володіти знанням усієї історії. Звідси випливає, що субстанційна філософія історії має телеологічну природу, «філософ-субстантивіст» уже «знає» мету всесвітньої історії, а сама ця історія розуміється як рух до цієї мети. Однак для знання мети історії, за А. Данто, філософ сам має бути присутнім при «завершенні історії», бути «свідком» iї завершення. А оскільки така позиція немислима, то історіософські побудови розкривають себе як пророцтва, тобто передбачається, що вся «світова історія» вже завершена. Як указує А. Данто, «на відміну від тих, хто прочитав увесь роман і з упевненістю здатний судити про значення тих чи інших подій у ньому, філософ історії не володіє знанням. Однак, незважаючи на це, філософ-субстантивіст оперує в термінах «всієї історії» й намагається, з одного боку, відкрити структуру всієї історичної цілісності, яку він екстраполює в майбутнє, а 3 іншого боку, у світлі цієї цілісної структури встановити значення подій минулого» $[4$, c. 18$]$.

Таким чином, згідно з ідеями А. Данто, судження про значення події передбачає знання іiі фіналу або кінця: ми можемо говорити про значення того чи іншого епізоду в тексті (наративі) лише завдяки тому, що знаємо фінал, кінець розповіді. Аналогічним чином і в історії судити про значення тих чи тих подій можна тільки тоді, коли ці події завершені, тому ставити питання про цілі чи сенс історичного процесу згідно з такою позицією не є коректним.

Якщо класична історіософія ставить своїм завданням вивчення значення тих чи тих історичних подій або процесів, то А. Данто під час дослідження структури наративних пропозицій доходить висновку про принципову незавершеність (незавершуваність) історичного пізнання й тлумачення минулого. «Наше знання про минуле, - стверджує А. Данто, - істотно обмежене нашим незнанням майбутнього. Установлення меж $\epsilon$ спільне завдання філософії, а встановлення цієї межі $\epsilon$ специфічне завдання аналітичної філософії історії в моєму розумінні» [4, с. 11]. За А. Данто, на противагу телеологічним побудовам традиційної субстантивної філософії історії, аналітична філософія історії має як своє основне завдання аналіз логічної структури історичного наративу. «Аналітична філософія історії не просто пов’язана 3 філософією, вона і $є$ філософія, але філософія, що застосовується для вирішення спеціальних концептуальних проблем, що виникають як у практиці вивчення історії, так і в субстантивній філософії історії» [4, с. 11].

Звернемо увагу, що в «аналітичної філософії історії» А. Данто не ставиться під сумнів саме розуміння історії, характерне для «субстантивної» філософії історії, a тільки показується неспроможність претензій на «знання кінця» і, отже, установлення «остаточних значень», або «справжньої суті», тих чи тих історичних фактів і подій. Однак з’ясування «логічної» й епістемологічної «неспроможності» традиційних 
метафізичних побудов зовсім ще не означає, що переглянуто сам основоположний принцип метафізичного мислення. Розуміння «історії» залишається в А. Данто спекулятивним і метафізичним. Висновки класичної історіософії відкидаються, а точніше, перевертаються (якщо в класичній історіософії імпліцитно передбачається можливість і осмисленість суджень про мету історії й значення тих чи тих фактів/ подій, то в лінгвістичної філософії історії А. Данто показується логічна неспроможність такого роду суджень), але вихідні презумпції метафізичного мислення залишаються непорушними. Показово, що та ж сама методологія прослідковується й у працях інших представників лінгвістичної філософської традиції $[6 ; 8]$.

Іншу спробу переосмислення підстав філософії історії здійснив Ф. Р. Анкерсміт у своїй роботі «Наративна логіка. Семантичний аналіз мови істориків». Його концепція історичного наративу істотно відрізняється від аналітичної філософії історії А. Данто. Наративна філософія історії - це не що інше, як теорія історичного наративу, історичної повісті.

Центральним питанням наративної філософії історії Ф.Р. Анкерсміт уважає питання про співвідношення «історичного наративу» 3 «історичною реальністю». Власну позицію з цього питання він визначає як «наративний ідеалізм» і протиставляє iii «наративному реалізму» класичної історіографії та історіософії. «Наративний ідеалізм проголошує автономність наративу: у наративі минуле описується за допомогою сутностей, якими не позначаються речі або аспекти минулого. Побудова й використання цих сутностей у наративі підпорядковується правилам, які не є простим відображенням закономірностей, існуючих в минулому, але мають свій власний статус» [1, с. 14]. Історичний наратив у зв'язку з цим не можна назвати «картиною» або «творінням» минулого в жодному з прийнятих значень цих слів.

Центральна теза Ф. Р. Анкерсміта полягає в тому, що «минуле» й «історія» самі по собі не мають наративної структури, а історіограф не має в своєму розпорядженні набору «правил перекладу» (із мови минулого на мову сьогодення), не має можливості «порівняти», зіставити історичний наратив із «самим минулим». «Ми знаємо, що минулому як такому не можна приписати наративну структуру; ми знаємо також, що не володіємо набором правил перекладу. Це означає, що якщо ми хочемо знати більше про цей механізм, нам доведеться проводити аналіз тільки на рівні наративів» [1, с. 137].

Головне завдання філософії історії як «наративної логіки» Ф. Р. Анкерсміт убачає в експлікації правил, що є підгрунтям будь-якого наративного оповідання й структурують наше знання про минуле: «Якщо саме минуле, усупереч припущенням, які $€$ підгрунтям наративного реалізму, не нав'язує нам особливих способів, якими воно має бути представлено в наративі, a, з другого боку, очевидне існування правил його наративного представлення, то ми повинні зробити висновок, що такі правила можуть бути знайдені тільки під час дослідження природи нашого наративного знання про минуле. У цьому й полягає позиція, яку я назвав наративним ідеалізмом» [1, c. 137].

Звернемо увагу, що центральне питання наративної філософії історії (про 
співвідношення історичних наративів 3 «історичною реальністю») узагалі не може бути адекватним чином сформульоване й розв'язане в контексті епістемологічної філософської традиції. Це пов'язано з тим, що в останній не проблематизується основа понять всякої історіософської рефлексії - «історія» й «історична реальність». Теза, що «минуле саме по собі не має наративної структури», є не що інше, як висловлювання про саме минуле, про саму «історичну реальність». Це висловлювання жодним чином неможливо вивести 3 аналізу наявної мови історіографії. Тут, отже, наративна (епістемологічна) філософія історії відступає від свого основоположного принципу: мати справу тільки 3 «мовою» (наративом) й утримуватися від висловлювань про «саму реальність».

Позиція «наративного ідеалізму» не може бути залучена й з аналізу історичних наративів, оскільки вона 3 неминучістю передує цьому аналізові. Інтуїтивній упевненості історіософії в тому, що минуле подібне «машині» i його можна адекватним чином репрезентувати в історичному наративі, тобто позиції «наративного реалізму», Ф.Р. Анкерсміт протиставляє настільки ж інтуїтивну впевненість у тому, що минуле саме по собі не має наративної структури, i спекулятивну позицію «наративного ідеалізму». Як і у випадку 3 аналітичною філософією історії А. Данто, ми маємо тут справу з простим перевертанням ключових тез класичної філософії історії, а не з їх критичним переосмисленням.

Таким чином, у контексті лінгвістичної традиції «філософія історії» трансформується в «теорію історичного наративу», яка є не що інше, як філософія мови. Філософія історії редукується до логічного аналізу наявного історіографічного наративу. Така редукція, однак, залишає нерозв'язаними й навіть непроясненими низку питань:

- На якій підставі можна робити які-небудь висновки про співвідношення «історичного наративу» й «історичного минулого»?

- Який онтологічний статус самого «історичного минулого»?

- Як зіставляються поняття «історичне минуле» й «історична реальність»?

- На якій підставі слід розрізняти «історичне» й «неісторичне» (позаісторичне)?

Ці питання не можуть бути поставлені в контексті аналітичної (епістемологічної або наративної) філософії історії. У той же час, відповіді на ці питання імпліцитно передбачаються у всякій теорії історичного наративу. Ці відповіді негласно й некритично запозичуються лінгвістичною традицією з класичної філософії історії як «теорії історичного процесу». «Історія» в межах лінгвістичної філософії історії залишається тим же, чим вона була i в класичній історіософії, тобто процесом зміни / розвитку об'єкта (або «сутності») у часі. Базовою для розуміння історії залишається метафора «процесу» або «розвитку» (тобто еволюції). Таким чином, i класична філософія історії, і наративна філософія, незважаючи на всю їх несумісність i різноспрямованість, спираються на загальне для них розуміння історії як процесу розвитку в часі.

Зазначимо, що, на відміну від умоглядних філософських побудов наративістів, у межах класичної філософії історії останнім часом було здійснено низку методологічних проривів, котрі дозволяють використати як емпіричну базу 
історичного дослідження наявний комплекс джерел, у тому числі такого важливого наративу, як статистичні дані, характерні для всіх аграрних імперій - від стародавнього Єгипту й Китаю до Османської й Російської імперій. Концепції еволюції суспільства, побудовані на підставі цих методів, уже довели свою аналітичну придатність не лише для адекватного пояснення історичного минулого (що підтверджено рядом незалежних одна від одної груп історичних джерел), але й для правильного прогнозування історичного розвитку в доступному для дослідження проміжку часу шляхом побудови наукових моделей $[2 ; 3 ; 5]$. Так, на сьогодні в результаті багаторазового емпіричного підтвердження отримують теоретичну завершеність розроблені на основі методології історичного матеріалізму концепції кліометрії, революційних криз та історичного розвитку як результату адаптації соціуму до змінюваних умов буття [9]. У той же час лінгвістична (наративна) філософська традиція поки що обмежується лише з'ясуванням базових підстав власної методології й умоглядною критикою методів опонентів (яка в більшості випадків не враховує реальний стан сучасної історичної науки). Прогностичний потенціал методології наративної філософії історії поки що не надає змоги адекватного використання його в реальних історичних дослідженнях, хоча ця методологія $з$ успіхом використовується для формування історичної свідомості, у тому числі й у професійному середовищі. Тому на сучасному етапі розвитку філософії історії лінгвістична традиція як методологія наукового дослідження видається значно менш перспективною, ніж методи, розроблені на підставі класичного історичного матеріалізму.

\section{Література:}

1. Анкерсмит Ф. Р. Нарративная логика. Семантический анали з язика историков / пер. с англ. О. Гавришиной, А. Олейникова. М. : Идея-Пресс, 2003. 360 с.

2. Воронянський О. Проблема суб'єктності суверенітету в контексті технології здійснення влади // Evropskypoliticky a pravnidiskurz. 2015. Vol. 2, Iss. 4. C. 205-209. URL : http://nbuv.gov.ua/ UJRN/evrpol_2015_2_4_32.

3. Воронянський $O$. В. Політичні інститути: механізм формування в конкурентному середовищі // Сучасне суспільство. 2014. Вип. 1. С. 15-28. URL : http://nbuv.gov.ua/UJRN/cuc_2014_1_4.

4. Данто А. Аналитическая философия истории / пер. с англ. А. Л. Никифорова, О. В. Гавришиной. М. : Идея-Пресс, 2002. 289 с.

5. Денисенко І.Д. Теорія соціального простору: евристичний потенціал щодо соціальнополітичних досліджень // Сучасне суспільство: політичні науки, соціологічні науки, культурологічні науки : зб. наук. праць ХНПУ імені Г. С. Сковороди. 2015. № 2 (2). С. $27-37$.

6. Дёмин И. В. Философия истории как региональная онтология. Самара : Самар. гуманит. акад., 2012. $202 \mathrm{c}$.

7. Кукарцева М. А. Аналитическая философия истории: вчера и сегодня // Полигнозис. 2009. № 3(36). C. 62-71.

8. Херрманн Фр.- В. фон .Фундаментальная онтологія языка / пер. с нем. И. Н. Инишева. Минск : ЕГУ; ЗАО «Пропилеи», 2001. 168 с.

9. Національний суверенітет: український вимір в контексті світової політичної думки / О. В. Воронянський, С. С. Євсєєв, Ю. В. Журавльов, Ю. В. Зайончковський [та ін.]. Харків : «Міськдрук», ХНТУГС імені Петра Василенка ; ХНУБА, 2017. 284 с. 


\section{Natalia Moiseeva, Svitlana Romanova}

\section{PHILOSOPHY OF HISTORY IN THE CONTEXT OF LINGUISTIC (NARRATIVE) PHILOSOPHIC TRADITION}

The authors consider the problem of the disciplinary status of linguistic (narrative) philosophy of history. The problem is examined in the context of analysis of its basic assumptions, which have been described in the works of A. Danto and F. R. Ankersmit. This philosophical tradition mainly developed in the first half of the twentieth century as a reaction to the impossibility of empirical verification of the scientific adequacy of the theoretical concepts of the regularities of historical development, which were established within the classic philosophy of history. Rejection of the gnosiological problematics lies on the basis of linguistic (narrative) philosophy of history. Also the notion of a fact is replaced by the notion of interpretation of a fact on the basis of narrative. The study of meanings and values of these narratives is based on language as the ontological Foundation of consciousness.

According to A. Danto the scientific failure of the theory (concept) of the historical process lies in the impossibility of assessment by the researcher of the entire length of the process, especially of the stage of completion (the «end of history»). The observer does not know the final result of the whole process. Therefore, the observer can not estimate the value and meaning both of a process as a whole and its individual stages. Thus, the conclusion is that the history as a series of past events cannot be the subject of the philosophy of history. Only the interpretation of history in the philosophical studies and narrative representations can be the subject of the philosophy of history.

According to F. G. Ankersmit «past» and «history» by themselves do not have narrative structure. The researcher also doesn't have a set of rules of language translation of the past into the language of modernity. These rules would allow to compare the historical narrative with the «past».

Thus, in the context of linguistic tradition the «philosophy of history» transforms into the «theory of historical narrative». This theory only logically analyzes the existing historiographical narrative. In fact, this position does not replace the basic methodological approach of classical philosophy of history to the study of reality (a theory based on the uncertainty of the outcome of the process). Only the subject of study is changed: the historical process is replaced by a historical narrative (not the source of the study of history but its interpretation).

This approach can be used for the formation of historical consciousness, but it is unsuitable for real historical research. At the same time in the frames of classical philosophy of history a series of methodologies have been recently created. These methodologies allow to use empirical research methods and build it on the basis of concepts. These concepts find a complete confirmation with the help of an independent group of historical sources. So, 
today, as a result of repeated empirical evidence the concepts of cliometrics, revolutionary crises, and historical development as a result of adaptation of society to changing conditions of existence are finally created. These concepts were developed on the basis of the methodology of historical materialism. At the same time a linguistic (narrative) philosophical tradition only explains the basic foundation of own methodology and criticizes the methods of the opponents. Predictive capability of the methodology of narrative philosophy of history doesn't enable to adequately use it in a real historical research, although this methodology has been successfully used for the formation of a historical consciousness, including professional surrounding. Therefore, at the present stage of development of the philosophy of history, linguistic tradition as the methodology of the research is much less promising than the methods developed on the basis of classical historical materialism.

Моіссєва Наталія Іванівна - доктор філософії, доцент, завідувач кафедри ЮНЕСКО «Філософія людського спілкування» та соціально-гуманітарних дисциплін Харківського національного технічного університету сільського господарства імені Петра Василенка.

Moiseeva Natalia Ivanivna - Candidate of philosophical sciences, Associate Professor, Head of the Department for UNESCO «Philosophy of Human Communication», Social and Humanitarian Disciplines, Petro Vasylenko Kharkiv National Technical University of Agriculture.

e-mail: kntusgunesco96@gmail.com

ORCID: 0000-0001-6349-7892

Романова Світлана Сергіївна - старший викладач кафедри суспільногуманітарних дисциплін Харківського національного університету будівництва та архітектури.

Romanova Svitlana Sergeevna - Senior Lecturer of the Department of Social and Humanitarian Disciplines, Kharkiv National University of Construction and Architecture.

e-mail:fotina0810@gmail.com

ORCID: 0000-0003-3857-7414

Надійшла до редакції 10.05.2018. Розглянута на редколегії 25.06.2018.

\section{Рецензенти:}

Доктор філософських наук, завідувач кафедри філософії Національного аерокосмічного університету ім. М.Є. Жуковського «ХАІ» Чернієнко В.О.

Доктор філософських наук, професор, декан гуманітарного факультету Національного аерокосмічного університету ім. М.Є. Жуковського «ХАI» Копилов В.О. 